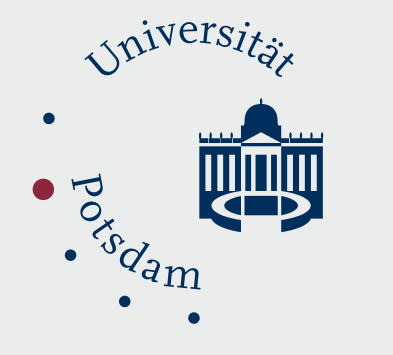

\title{
Faculty of Arts
}

Lars Eckstein | Andrew Wright Hurley

\section{German-Australian Colonial Entanglements}

On German Settler Colonialism, the Wavering Interests of Exploration, Science, Mission and Migration, and the Contestations of Travelling Memory 

German-Australian Colonial Entanglements 

Lars Eckstein | Andrew Wright Hurley

\section{German-Australian Colonial Entanglements}

On German Settler Colonialism, the Wavering Interests of Exploration, Science, Mission and Migration, and the Contestations of Travelling Memory 
University of Potsdam 2020

Published online at the

Institutional Repository of the University of Potsdam:

https://doi.org/10.25932/publishup-44449 


\section{German-Australian colonial entanglements:}

on German settler colonialism, the wavering interests of exploration, science, mission and migration, and the contestations of travelling memory

Lars Eckstein and Andrew Hurley

In this volume, we set out to explore various trajectories of German and Australian colonial pasts; the ways in which their histories are intricately entangled, and how they have been, and continue to be, remembered, in a range of different German and Australian contexts. We use the metaphor of 'exploration', here, quite aware of its tricky colonial baggage. In order to bring out some of the conceptual challenges of German-Australian colonial entanglements, let us begin this introductory essay, therefore, with two vignettes about actual exploration: The first takes us to back to the year 1843, and the moment when the Prussian natural historian Ludwig Leichhardt first crossed Myall Creek in the northern reaches of New South Wales. It is a moment, we will argue, which foregrounds and helps to conceptualise some of the ambivalences and abysses of colonial entanglement. The second vignette fast forwards to our time, and to our own attempts to find traces of Leichhardt in Pioneers Memorial Park in the Sydney municipality of Leichhardt. It will foreground the aspect of remembering in the title of this volume.

\section{Crossing Myall Creek}

Sometime in May 1843, the Prussian explorer Ludwig Leichhardt crossed Myall Creek. He did so on extensive travels between Sydney and Moreton Bay in the Brisbane area, about a year after he first arrived in Sydney in February 1842, and about one-and-a-half years before he departed on his triumphant first expedition from Moreton Bay to Port Essington 
on the northern coast of the continent. The overland expedition to Port Essington was to make Leichhardt famous as the explorer who 'opened up’ Queensland, and secured his standing as celebrated natural historian both in Europe and Australia. ${ }^{1}$ His third expedition, on which he attempted to cross the continent from east to west, from Moreton Bay to the Swan River, was to make him a legend: For Leichhardt and his entire expedition team disappeared without a trace somewhere in the heart of the continent. ${ }^{2}$

In 1843, Leichhardt was not yet famous, nor a legend. He was the son of an ordinary peat inspector from the village of Trebatsch in the Brandenburg provinces who managed to secure an excellent university education in Berlin and Göttingen, and gathered further training in Paris and London. Without ever completing any of the numerous degrees he started, he decided to travel to Australia to make his name as an explorer and natural historian in the style of the famous Alexander von Humboldt. Unlike his idol, Leichhardt had none of the privileges of an aristocratic background, of membership in royal societies, or of financial means. His designs were therefore dependent on the support of the Australian landed gentry, whose interest was not in Leichhardt's scientific discoveries, but in the uses of the land that he would cross. On the day he crossed Myall Creek, Leichhardt was on his way north to the Moreton Bay frontier, where he would soon spend eight intense months researching the natural history among the local Indigenous population. ${ }^{3}$ In the months before, he had spent much time around Newcastle and the Hunter Valley. There, he was hosted by one of the most influential settler families in colonial New South Wales, the Scotts. He had been introduced to the three Scott brothers during his first months in Sydney after his arrival in Australia. Among these brothers was Robert Scott, a settler aristocrat with political ambitions and a vast estate in the Hunter Valley.

When Leichhardt trailed his horse through Myall Creek on a late autumn day in 1843, he was in the process of crossing the frontier between the estates and interests of the early British colonial society, and the Indigenous communities beyond. Yet the image of Leichhardt crossing Myall Creek contains more convoluted layers of meaning. It is loaded with a symbolic significance that we think is emblematic for the ambivalences and abysses of German-Australian colonial entanglements at large, and the difficulties of remembering them adequately. 
The word 'myall' itself already speaks of that complexity: It goes back to a Dharuk (also Dharug) word from the Sydney basin, signifying 'stranger', originally reserved for a person from another tribe. 'Myall Creek', however, would have received its name not from the Dharuk people, but the early white settlers. In the process of colonization, they picked up 'myall' and began to use it as a derogatory term for, in their racist logic, 'wild' Indigenous Australians living in traditional ways beyond the frontier. Leichhardt, it seems, was a stranger to both of these senses of 'myall'. In his diaries, he exclusively refers to myall in the denotation that has survived to this day: as a botanical category, labelling a specific type of acacia tree in the region. This is also how his fellow botanist, Robert Lynd, used the term in an 1845 'elegiac ode' commemorating his friend whom he (falsely) presumed 'murdered' on his expedition to Port Essington. The ode is to Leichhardt, as much as to the 'Enlightenment' that he inaugurated:

And be those happier times at hand When science, like the smile of God, Comes brightening o'er that weary land, How will her pilgrims hail the power, Beneath the drooping myall's gloom, To sit at eve, and mourn an hour. And pluck a leaf on Leichhardt's tomb! ${ }^{4}$

Lynd's image of the weeping myall trees intricately plays on both earlier connotations of 'myall', mourning the death of a 'stranger', killed by 'wild' Indigenous people. Leichardt, in contrast, was, or preferred to be, oblivious to the ambiguous connotations of the landmark that he crossed and the botany he described. At Myall Creek in particular, this oblivion is given an additional twist: For less than five years prior to Leichhardt's crossing, Myall Creek acquired yet another connotation. It became the name of the most widely publicized massacre of Indigenous people at that time in Australian colonial history.

Myall Creek in all of its multiple signification thus invites reflection on the roads taken or not taken by Leichhardt in the face of the death and annihilation in the areas that he traversed, occurring both before him, as in the case of the Myall Creek massacre, and in the wake of his later travels in what was to become Queensland. ${ }^{5}$ Myall Creek is hence also an epistemic watershed in the sense that it marks a challenge to Leichhardt's specific 
ways of knowing the land. The image of Leichhardt crossing Myall Creek demands us to question the purported innocence of the natural history approach he followed, with Humboldt as his guide, and to foreground that approach's profound colonial entanglement.

Here is how Leichhardt himself describes crossing Myall Creek on 31 May 1843 in his diaries:

From Norris's to Dangar's station on Myal Creek firstly silver-leaved ironbark ridge, then rich black earth plains with basaltic base covered with box. It has the character of Cassilis. It is a beautiful run, very vigorous grass growth.

From Myal Creek (Dangar's station, Hunger Station) open undulating country with myal and box, oat grass, wool oats, black basaltic soil, pieces of basalt visible everywhere. The track led to a range of hills. In Myal Creek basalt, blue clay slate, thermantide, pieces of quartz. Opposite the hut basalt outcrops, commonly vesicular. ${ }^{6}$

Leichhardt's prose is typically unspectacular; but it is a characteristic example of his way of encountering and reading the land. It is revealing of what Simon Ryan calls the 'cartographic eye', ${ }^{7}$ or Leichhardt's taxonomic gaze, a gaze which immediately ties keen observation to the progressively expanding categories of the geographical, botanical and geological sciences. It is a gaze, moreover, which is split between an almost religious desire to know the world and creation - one to which he would give wing in some of his letters home $^{8}$ and which would famously be portrayed and parodied in Patrick White's novel $\operatorname{Voss}^{9}$ - and a more profane desire to measure, quantify and provide knowledge for an expanding imperial economy. ${ }^{10}$

Leichhardt's ambivalence is deepened by the recent history of Myall Creek, of which he may or may not have been aware. At least there is no mention in his diaries and letters that a little less than five years earlier, in June 1838, at least 28 Indigenous men, women and children who sought protection at Henry Dangar's station on Myall Creek were brutally massacred by a marauding group of twelve stockmen. The massacre itself was not a singular or extraordinary event in Australian history; in fact, it was the third in a row committed by the same group, and it was one of countless others of varying scale in the region, the most notorious being the Waterloo Creek massacre earlier in the same year. Myall Creek gained its special significance because the atrocities were reported, investigated, and brought to court. And while in the first instance, charges were dismissed 
against all of the defendants, seven of them were found guilty of murder in a retrial, and hanged. The second Myall Creek trial in December 1838 was the first and only trial in Australian colonial history in which white men were convicted for murder after a massacre of Aboriginal people. As such it changed relations between settlers and Indigenous Australians - not by reducing the number of killings, but by promoting more clandestine methods of murder, and a politics of silence. ${ }^{11}$

Can Leichhardt really have not known of the events at Myall Creek? Some of the bitter ironies of his silence transpire when compared with an earlier diary entry, recounting a scene in Sydney where he met an enigmatic Robert Scott. On 5 August 1842 Leichhardt records:

I saw the three brothers: [Walker Scott], Robert Scott and Captain Scott. While Walker fascinated and amused me by his kind good humour, I felt that in Robert I faced a thinking man, whose life is always directed towards the practical side, which, however, he seeks to grasp and command with his mind. He is called no other than 'mad Bob'. Why? - is not clear to me yet. [...] Am I deceiving myself, if I believe that I could be of greater avail in the practical field? ${ }^{12}$

What may well not have been 'clear [...] yet' to Leichhardt, was Robert Scott's key role in the Myall Creek trials. For it was none other than Robert Scott who organized the stockmen's defence. For this purpose, Scott formed a secret association with the express aim of maintaining the legality of killing Indigenous Australians, and to which apparently most landowners north of Sydney subscribed. Scott raised 300 pounds, hired the best lawyers in Sydney, visited the accused in prison, and personally devised their defence strategy. After the triumphant success of the first defence, however, the tables dramatically turned for Scott. Following the second trial, he was stripped of his office as Magistrate and he largely withdrew from the public. The Myall Creek massacre and its legal and social effects thus rather uncannily throw into relief Leichhardt's attraction to 'mad Bob' and his intellectually controlled 'practical side'. And it raises more fundamental questions about the ways in which the sciences to which Leichhardt devoted his life can be disentangled at all from those more 'practical fields' of imperial conquest. ${ }^{13}$

However, is it too easy to see Leichhardt, the Prussian naturalist in a British colony, simply in terms of silence and complicity? On close inspection, Leichhardt's diary entries 
between 1843 and 1844 show traces of an increasing awareness of other possibilities, and perhaps even of his own conflicted position in the imperial project. Leichhardt, one could say, symbolically crossed Myall Creek anew, the more he engaged with the Indigenous population around Durundur Station in the Moreton Bay region where he stayed between July 1843 and March 1844. He did so by acknowledging, at least in part, other ways of being and knowing the land, although he was never able to resolve the tensions between such knowledge and the universalising narratives of Western science by which he lived. Leichhardt came a very long distance in this process, a path that was hardly straightforward, but punctured, full of sidetracks, and fraught with obstacles and irritations. Due to the inadequacy of his often fragmentary diary entries, and the presence of what Robert Sellick and Marlis Thiersch identify as multiple Leichhardts in his diaries ${ }^{14}-$ the recorder, the editor, the adjudicator - this path often becomes altogether untraceable; lost in the thickets, as it were. Let us nevertheless try and provisionally signpost it with three passages, one dating to just after his departure from Sydney in September 1842, the others set down after he crossed Myall Creek.

Some three weeks after meeting Robert Scott in Sydney, Leichhardt is shown a collection of Indigenous skulls in Newcastle. On 25 September he records:

Mr. Bolton, a customs-official, had shown me his skulls of Aborigines. [...] There was a number of interesting indentations on the outer surface of the skulls of the women, which result from blows, which the men rain on the women. That portion of the women's temporal bone, which is behind and above the ear-hole is strongly vaulted (this part corresponds to Gall's Destructiveness). [...] It is amazing what hard blows on the head these savages can stand. Mr. Bolton told me that they confer blows on each other with their waddies freely and in turn. ${ }^{15}$

This passage is vital as it marks how Leichhardt's early encounters with Indigenous Australians are scripted by the same taxonomic gaze with which he analyses rock formations, plants and animals. It does not occur to him, it seems, to question the possible origins of the skulls, or to seek less ridiculous ways of explaining the 'interesting indentations' on some of them. The violent politics of the frontier are overwritten by the disinterested politics of the scientific Enlightenment that he carried with him from London, Paris, Berlin, or Göttingen, where he would have encountered Franz Josef Gall's phrenological theories, probably in anthropological lectures of his favourite professor, 
Johann Friedrich Blumenbach. Blumenbach was one of the fathers of physical anthropology, and advanced the idea that there were five different races or 'variations' in the human. ${ }^{16}$ Travelling in Leichhardt's baggage with him to Australia, the European Enlightenment's racial imaginary effortlessly blended in with the racial rhetoric of settler society, as in the uncanny conclusion of Leichhardt's reading of the Indigenous skulls: 'Their addiction to drink, however, destroys them, and they disappear like the snow from the mountains in the summer sun'.

How far did Leichhardt travel away from the abyss of such similes? Again, the path is difficult to make out. But some four months after he crossed Myall Creek, and some two months after he arrived at Durundur, the diaries increasingly document reflections about Indigenous knowledge that Leichhardt draws from a range of Indigenous people in the Moreton Bay area, for example on September 18, 1843:

The next morning [...] we were occupied in the scrub of the Bunya Bunya Range. The sharpness with which the Blacks differentiate the various trees of the scrub is extraordinary. More than 50 different trees were distinguished and hand specimens of bark and wood and specimens of leaves or fruit and blossom were collected. Each of the three language families had its own name for each tree. In the process they are so certain that all specimens with few exceptions would be recognised again by the Black kippers on Archer's station, although they had not accompanied us. I recognise how important it is to be accompanied by Blacks, and how desirable it would be even for my science to associate with Blacks during our expedition. ${ }^{17}$

The passage indicates how Leichhardt gradually came to appreciate Indigenous perceptions of the land, and how he attempted to productively align them with his own taxonomic universe, not exclusively by means of appropriation, but in an exchange that becomes increasingly mutual, and gradually extends also to an interest in Indigenous ways of knowing, partly documented, here, in his keen interest in Indigenous languages. The private journals indicate that he also collected Indigenous lore, and in distinction to many other scientists before and after, mostly took the trouble to record the identities of his informants. ${ }^{18}$ It is also significant that, unlike some other explorers including, in the Australian setting, Burke and Wills, Leichhardt had the sense to rely heavily upon Indigenous guides on his exploratory travels and that he discussed them in his published Journal of the Port Essington Expedition. ${ }^{19}$ Indeed he granted Charley Fisher and Harry 
Brown a respectful portrait in the Journal, and Dane Kennedy notes that the two men 'loomed large' in the book. ${ }^{20}$

Toward the end of the road, however, there is not a resolution, rendering Leichhardt a 'friend of the Aborigines', but rather what appears to be an unbridgeable gap between his continuing obligation and, perhaps, attraction to the likes of Robert Scott on the one hand, and to the Indigenous people he came to live with and learn from on the other. While this conflict is nowhere explicitly formulated or negotiated in the diaries, its profound depth transpires in a forthright diary entry dating to October 3, 1843. Still at Durundur, Leichhardt's records views on Australia's Indigenous people that culminate in a plea for an unflinching politics of imperial assimilation that anticipates nothing less than the Stolen Generations, that is the forced removal of Indigenous children from their families:

There is a means to preserve them - this means, o hear you pseudo-philanthropists, who want to judge all their circumstances only according to your narrow horizons - this means is slavery. [...] We must take the young generation of the old tribes by force, educate them, compel them to work and so get them used to work. ${ }^{21}$

However, he was evidently unable to stand by this sentiment. Rereading this very diary entry after his return to Sydney, he edited it by scribbling the following note on the margins, a note that we read as a private acknowledgement of Indigenous resistance against assimilation and conquest that is much more than a romantic gesture:

Although slavery seems the only means to preserve these tribes and in the course of generations to civilise them, I would prefer to see them die in freedom than be civilised in slavery. That is my opinion on 15 February 1844 and it will probably remain forever. ${ }^{22}$

Is it possible to make out in the unbridgeable gap between these two statements, in the dramatic silence in-between, an inkling that there is no innocence in the task of scientific exploration and observation which he had set for himself? A registering that you can cross Myall Creek, but that it is far too wide to keep a safe footing on both banks?

\section{Looking for Leichhardt in Leichhardt ${ }^{23}$}


Fast forward 170 years, to another 'exploration' party. There is something peculiar about wandering around an ex-cemetery on a hot day, looking for a memorial to someone who was not even buried here. Between 1868 and 1912 over ten thousand colonists were buried at what is today Pioneers Memorial Park in the Sydney suburb of Leichhardt. How many Indigenous bodies might have been interred here before or after 1868, is not recorded. Not that there is much evidence of any of them now, other than a vaguely disconcerting, funereal air, or perhaps we are imagining it. The gravestones were all removed prior to 1922, when the allotment opened to the people of Leichhardt for their recreational enjoyment. It became a massive, largely indiscernible grave, marked only by a small plaque behind the entrance arch, advising: 'Particulars concerning the interments in the area may be obtained on application to the Leichhardt Town Hall'.

Ludwig Leichhardt probably never visited this place, least of all when it was operating as a cemetery. He had most likely been dead twenty years before it first opened. But he is here in spirit. Apparently a tree was dedicated to the missing explorer in 1963 to memorialise his sesquicentennial - another step in the long and contested process of commemoration of the Prussian explorer, probably inaugurated in 1845 by Robert Lynd in the poem cited above. ${ }^{24}$ And that 1963 tree is what we are looking for today. It is an obvious spot: a site in the municipality of Leichhardt officially dedicated to the commemoration of pioneers. Yet that choice is also filled with irony. The first thing you see after the main entrance is a memorial to the 'Men of Leichhardt' who served and died in the Great War a memorial to another set of absent bodies. How might they have felt about coming from Leichhardt, and fighting against Leichhardt's countrymen? At a time when GermanAustralian relations reached their nadir, with Germans and German-Australians interned, and Germanic place names erased (but notably not Leichhardt in Sydney)? A time when, conversely, a surprisingly large number of men of German extraction served as soldiers in the Australian Army? ${ }^{25}$ The shadow of that war and the next complicated the Australian commemoration of the explorer in 1963 when the tree was planted. The wars were living memory, and Alec Chisholm’s 1941 anti-hagiography of Leichhardt, Strange New World, still set the tone, including by way of its influence on Patrick White's epic fictionalisation of the German explorer in Voss. ${ }^{26}$ 
In the end we don't find any obvious 'Leichhardt tree', despite looking at everything that is passably fifty years old. There are memorials everywhere in this palimpsest of a park; trees planted to commemorate the founding of the Australian Labor Party, and the National Day of Action Against Sexual Violence; plaques about sustainable transport; and an obscure slab of sandstone with the words 'Tuber', 'Leaf', 'Stain'. Only one tree looks plausibly memorial, but it is too young, and the boulder at its base does not bear an inscription, although it looks as if it should. An unfinished re-planting perhaps? Or just another phantom? The only clearly German thing we find is some new playground equipment adjacent to a treehouse that is off-limits. 'Unstable - keep clear': A fitting title for an inconclusive 'Leichhardt tree', of which there have been so many found all over Australia in the years since he disappeared, with the initial ' $\mathrm{L}$ ' carved into them. ${ }^{27}$ But this one also seems too young. The German equipment is evidently used by today's children of Leichhardt, whose painted tiles decorate the playground. Children like Elio and Doan, whose names bespeak other histories; of post-war migration, and the 'multicultural' makeup of the suburb of Leichhardt.

By far the most prominent thing in the park, though, is the oversize Rotunda erected to mark Australia’s Bicentennial of European settlement in 1988. It is getting little use today, despite the fact that it is a wifi hotspot. Rusty and neglected, it is a strange throwback to the nineteenth century era of bandstands and monuments, but with cast iron finials substituted by brutal steel girders. It does not seem to know what it wants to be, other than big - a big statement from a time when the Federal Labor government very much wanted grand celebrations, including in the international arena, but was anxious about how to engage with Indigenous protest against the Bicentennial. Could the 1963 Leichhardt memorial tree have been grubbed out to make way for this construction? A superannuated relic, a bit like the 10,000 graves that had been disinterred earlier in the century?

Still, we need to accept our failure - no visible traces whatsoever of Leichhardt in the Park. In visiting Pioneers Memorial Park, we thus in a way joined the legion of recent searchers and re-enactors who have failed to find Leichhardt's remains but who had a good time doing it. How much more rewarding the task when you don't have to restrict yourself to a small park but have a whole continent! But then, to what extent are we, as latter-day searchers, retracing what Leichhardt himself did, and what various other searchers did 
when they used him as an excuse to be out in the Australian interior? White absence 'guarantee[ing] white male presence'; ${ }^{28}$ obsessing over him and inconclusive relics in a way that obscures the colonial processes of settlement and Indigenous displacement in which he was entangled, and of which he was, as his diaries would suggest, perhaps half aware?

We are more successful further down Norton Street at the Leichhardt Town Hall. Here a much smaller piece of metal than the Rotunda marks the Bicentennial: It is a bronze bas relief of Leichhardt given by the East German 'Peoples' Friendship League' to the people of Leichhardt in 1988, at that time led by a particularly 'red' Town Hall under Mayor Nick Origlass and his associate Issy Wyner. ${ }^{29}$ If, as Lindsay Barrett suggests, Leichhardt has had many lives, ${ }^{30}$ then one of them brought him here from the communist state.

Geographically, Leichhardt was an East German inheritance, but memorialisation of him there was patchy and contested. He was tainted since his name had been invoked in the Nazi 'Aryanisation' of Slavic place names in his home region, Lusatia, during the late 1930s. ${ }^{31}$ And he was viewed by some post-war cadres of not having said enough in favour of Australia's Indigenous population. However, he could also be made to do useful ideological work in the Cold War era, and perhaps even inspire budding young socialists to devote themselves to the betterment of man. Hadn't the 'humanist' Leichhardt done just such a thing through his dedicated scientific questing in Australia? Old guard East German sceptics about Leichhardt were ultimately outpaced when the German Democratic Republic sought out trade ties and legitimacy via diplomatic relations with the nonCommunist world, a fact that saw the establishment of an embassy in Canberra in 1973 and the deployment of Leichhardt as shared East German-Australian heritage. ${ }^{32}$ In 1988 a convenient double anniversary marking the explorer's 175th as well as white Australia's 200th birthday - the German Democratic Republic seized upon him as a 'figure of integration' between East Germany and Australia, as Joachim Elm, the then East German ambassador in Australia, put it. ${ }^{33}$ The fruits of that initiative were a Leichhardt symposium with Australian participants held in East Germany, a bronze bust of Leichhardt destined for the new Parliament House in Canberra, and this relief at the Town Hall. Its installation was combined with an exhibition about how Leichhardt was honoured in East Germany, 
and was supposed to prompt the people of Leichhardt to recognise the explorer's accomplishments and, through him, the German Democratic Republic and its achievements. But it was accompanied by a slightly guilty conscience on the East Germans’ part about Indigenous attitudes to the Bicentennial.

This deliberate use of history by a State anxious about its international legitimacy is maybe not so far removed from the Bicentennial Rotunda. One Leichhardt moment, with two states each uncomfortably negotiating and trying to accommodate Indigenous sentiments at the same time as celebrating white settlement? ${ }^{34}$ Having finally found Leichhardt, we approach the relief with some trepidation, expecting it to be an example of the 'socialist realist' mode of sculpture we have witnessed in various places in the East; something actually to rival the heavy-handedness of the Bicentennial Rotunda. However, it is a surprisingly soft image of Leichhardt; a relief in a different sense of the word. We learned from Elm's archived files that its sculptor, the East German Gertrud Salomon, had struggled to render Leichhardt as both 'dynamic' yet 'human'. ${ }^{35}$ In this process, she succeeded in realising a Leichhardt who lives on, looking out with curiosity from his place on the wall of a local council chamber, despite the demise of the Peoples Friendship League and the State that brought him here.

\section{German-Australian Colonials Pasts}

We chose to open this volume with these two vignettes - one historical, one contemporary - because the notions of entanglement and memory represent the two themes around which the contributions to our book cluster, attending to one or the other, and oftentimes both. This book is a product of three consecutive research projects, during which we and our collaborators have attempted to add our own critical edge to the ways in which GermanAustralian colonial entanglements are remembered, and to assess how its pasts are, like Leichhardt's relief, looking out on the futures of Germany and Australia: a postreunification Germany still grappling with the legacies of fascism and the two Germanies which followed it, yet which is by and large still unwilling to address, let alone accept, the responsibilities arising from the atrocities of German colonialism. And a post-apology 
Australia that continues to be in denial about its postcolonial obligations to the original owners of the land. The figure of Ludwig Leichhardt has been a key one whom we have pondered in our projects: Leichhardt is an emblematic figure who crystallises critical debates around Germany's colonial entanglements before Bismarck and the establishment of actual German colonies in Africa, the Pacific and China between 1884 and 1914/18, yet he is also a highly ambivalent figure in Australia's own mythologies of nation building and extraterritorial adventure. To explore such entanglements, we organised an international conference and facilitated an exhibition on the occasion of Leichhardt's 200th birthday in 2013, in Schloss Branitz, near Leichhardt's birthplace. The exhibition was curated by our friend Heike Hartmann, subsequently co-curator of the Deutscher Kolonialismus (German Colonialism) exhibition at the German Historical Museum in Berlin in 2016. ${ }^{36}$ Additionally, we organised two Sydney conferences on Leichhardt and other German colonial actors in Australia, and initiated an online resource of '1001' Leichhardt narratives with the Museum of Queensland. ${ }^{37}$

In all of our projects, and in this book too, we do not use the term 'colonial' to exclusively denote a historical period - in modern Germany, that would be 1884-1914/18; in Australia (as a collection of British colonies), it would be 1788-1901, but as a colonial master (in a New Guinea partly wrested from Germany), 1906-1975, with interruptions. Rather, colonial first and foremost describes a set of relations, discourses and practices which sustain historical processes of colonisation, processes which do not, or not necessarily, end with official pronouncements of the independence of formerly colonised nations, or the emancipation of formerly disenfranchised or disempowered groups within nation states. We read the notion of 'colonial' very much in line with Foucault and Said, as ultimately a function of power that plays out in a range of interconnected fields: economic, military, political, juridical, and, encompassing all the former, epistemic. Colonial relations, discourses and practices build on specific ways of knowing and ordering the world, and on ways of disavowing, or subjugating others.

Seen from this perspective, German individuals and the epistemic traditions they brought with them have been deeply entangled with the Australian colonial project, even if Australia was never a German colony per se. More specifically, we argue that German actors and interests played a key role in Australian 'settler colonialism', defined by Patrick 
Wolfe as a structure rather than as an event, premised on occupation and the violent displacement of Indigenous peoples rather than on conquest in the name of a single nation state. A key argument in settler colonial studies is that settler colonialism, as opposed to state-sponsored imperialism, is still ongoing today, given that structural racism, expropriation and disenfranchisement persist and profoundly affect the present and future. ${ }^{38}$ While the legacies of the British Empire and of British actors loom large in settler colonial studies, especially in North American and Oceanic contexts, Germany and German actors have been largely sidelined by existent scholarship. Against this trend, we propose that Germany, too, must face the present obligations that arise from its colonial pasts, including pasts where settler colonialism was enacted in the name of the state (as in Southern and Eastern Africa), and such pasts where it was not.

As amply demonstrated by the extant historiography and literary studies about German Australiana, going back at least to Augustin Lodewyckx's 1932 publication Die Deutschen in Australien, German speakers have been intricately involved in imagining, knowing and occupying Australia. ${ }^{39}$ In the pre-colonial period and afterwards various creative writers imagined Australia. ${ }^{40}$ Ludwig Leichhardt is only one in a long line of German-speaking explorers and scientists who contributed to Australia's colonisation, arguably beginning with Johann Reinhold and Georg Forster, the father and son naturalists of James Cook's second circumnavigation of the planet, who never actually set foot on Australian soil, but wrote about it extensively. Some of the Forsters' successors were much more deeply involved, as indeed German-speaking scientists were in a range of British colonies, particularly during the early Victorian period, a time of Anglo-German affinity. German-born Victorian Government Botanist Ferdinand von Mueller, for instance, was one of the most active explorers, scientists and geographers in the Australian colonies between the 1850s and his death in 1896 (and incidentally was also an ardent advocate for search expeditions to find Leichhardt). Mueller had an investment in the British colonial project, but he was also a staunch, if necessarily circumspect, proponent of German imperial conquests in Africa and the Pacific. And there were numerous other naturalists, including Charles Ruemker, Ludwig Preiss, Georg Neumayer, Amalie Dietrich, Richard Slemon, Otto Finsch and many others. Indeed, historian of science Rod Home famously suggested that science was a 'German export to nineteenth century Australia'. ${ }^{41}$ 
Science, however, was hardly the only site in the German-Australian entanglement, during the colonial proper period, and afterwards. There were, for example, numerous waves and moments in German settlement in Australia, driven by European religious discrimination, the failed revolution of 1848, and other factors. ${ }^{42}$ Another significant site was German missionisation, whether under a British aegis or carried on by bodies like the Moravians, or the Hermannsburg Missionsanstalt (see e.g. Felicity Jensz's and Andrew Wright Hurley's contributions to this volume, and the literature they cite). There were, too, German anthropologists, whether missionary-anthropologists like Carl Strehlow at Hermannsburg (Ntarea) in Central Australia, or their secular counterparts who form another site of entanglement. ${ }^{43}$ This also includes German anthropologists engaging with Australia in a more remote way, including by way of examining visiting Indigenous performers to Germany, as in the case of Rudolf Virchow in the $1880 \mathrm{~s}^{44}$ (for Virchow's role in the trade of Indigenous ancestral remains to Germany for raciological research, see the contribution by Lars Eckstein to this volume), or by way of extended research trips in Australia, such as by Hermann Klaatsch between 1904 and 1907. ${ }^{45}$ And not least, of course, there are the German merchants who maintained economic interests in the British colonies, including Leichhardt's friend, the immigration agent and propagandist as well as honorary consul for Hamburg, Wilhelm Kirchner, or the shipping magnate, J.C. Godeffroy, who profited handsomely from German emigration to the Australian colonies, as well as the circulation of goods and other articles that it enabled. ${ }^{46}$

\section{Colonial Entanglements and Entangled Memories}

How we ought to interpret the German role in different imperial projects around the globe, and in Australia in particular, is a matter of heated debate. Within the field of international German Studies, two opposing positions flagged out in the late 1990s by Susanne Zantop

on the one hand, and by Russell Berman on the other, still prevail. ${ }^{47}$ Berman's position is that Germans’ pre-1870 investment in colonialism was a largely disinterested affair, driven by a passion for science and the extension of knowledge rather than conquest. Readings along this line investigating the Australian complex continue to stress that German colonial 
actors were mainly concerned with scientific and ethical knowledge production - collecting plants, collecting animals, writing poems, saving souls - and thus imagined themselves much more as cultural agents than colonisers. While this view acknowledges that the production of those new knowledges existed within colonial conditions of possibility, such readings argue that they were not necessarily acting within an exploitative, economic frame and could sometimes even be at odds with it. This type of view is consistent also with interpretations that stress the increasing 'Anglo-German antagonism' that set in especially in the decades leading, from German unification in 1871 up to World War I. ${ }^{48}$

Zantop, by way of contrast, emphasizes that despite the fact that before the late 1800s there was little state-sponsored German colonialism and that after 1914/18 it came to a formal end, Germans invested heavily in imperial activities and fantasies that crucially both prefigured imperialism proper, as well as informed twentieth-century German fascism. This position fundamentally mistrusts (self)ascriptive readings which assert German exceptionalism, but highlights the intimate connections of German states and individuals in a common European endeavour to colonise the world.

Our concept of 'colonial entanglements' wishes to productively bridge the schism between the Berman and Zantop interpretations. Against Berman, the concept stresses the impossibility of disentangling the fields of science, religion or art from more obvious economic or military processes of exploitation, displacement or annihilation. Our opening vignette of Leichhardt crossing Myall Creek demonstrates exactly this: That there can be no disinterested science, religion, or art within the framework of the Australian colonial; that the production of colonial knowledge (geographic, geological, biological, anthropological, theological, aesthetic) inevitably ties in with settler colonial orders of violence and destruction. Yet partly against Zantop, the Myall Creek opening also cautions against a grand narrative that subsumes all German colonial activities in Australia under this order without allowing for more differentiated subject positions. Leichhardt's various crossings of Myall Creek show that there were changing degrees of reflexivity about one's inevitable colonial entanglement, and that there are various modes of avowing, and of disavowing it.

Our notion of German-Australian colonial entanglement also takes a cue from the work of Ulrike Kirchberger, ${ }^{49}$ who analyses how individuals in the British colonies could 
become involved in what she, borrowing from Robert Stafford's earlier scholarship on the British geographer Sir Roderick Murchison, calls the 'sub-imperialism' of science, performing an important role at the colonial periphery. Victorian Government Botanist Ferdinand von Mueller is one of her examples of how Germans could take on a role that Anglo-Australian actors typically filled. Mueller could become an advocate of AngloAustralian science, exploration, and settlement. But, critically, via his network with German-speaking scientists, Mueller could also promote German colonial enthusiasm, at a time when an empire was still a rather distant possibility, domestically. Indeed, his remoteness from Germany acted as a type of multiplier for this, she argues. Whilst Mueller remained in Australia and that restricted his ability to publicly advocate for German colonialism - not least due to rival claims over New Guinea in the 1880s - other German sojourners such as Georg von Neumayer returned and took up roles in the unified Germany, and could be much more vocal. In some cases, their experience in British colonies then acted as another type of colonial multiplier, once the German Empire proper was founded, with Neumayer as a case in point. In later work, Kirchberger and Ellis have advanced recent scholarship that increasingly questions the teleology of the rising Anglo-German antagonism, stressing the mutual engagements and entanglements that continued to be possible right up until 1914. ${ }^{50}$

Yet what about the present reverberations of German settler colonialism in Australia, and how such historical entanglements are remembered? Much of the extant German-Australian literature tends to positivistically record German 'contributions' to the colonial era in Australia, rather than to focus on the ambivalent legacies of histoires croisées, and how they have been selectively forgotten or called to mind in a range of diverging mnemonic policies. ${ }^{51}$ How, then, might we analyse how German-Australian colonial entanglements have been forgotten and remembered in the past, and in different locations? How may we adequately remember these entanglements now? Memory studies from Maurice Halbwachs to Pierre Nora and the Assmanns have reminded us of the work that memories of the past do in the present, how different collective memories can jostle for attention, and they have advanced useful analytic tools, such as the idea of the lieux de memoire. ${ }^{52}$ However, they have notoriously remained focussed on processes of collective memory within the framework of the nation. ${ }^{53}$ For the purposes of our project, memory 
thus needs to be fundamentally reconceived as a more dynamic category that cannot be contained by the nation. Several scholars have advanced productive models of memory as 'multidirectional', 54 'transcultural' and essentially 'travelling'. ${ }^{55}$ Astrid Erll postulates the inadequacy of the concept of 'culture' itself to account for modern memory practices, especially when tied to the limiting container of nation devised for it in the nineteenth century: 'Methodological nationalism in memory research therefore means an unnecessary restriction to the field', she notes: 'But a transcultural perspective also implies questioning those other grids (territorial, social, temporal), which we tend to superimpose upon the complex realities of remembering in culture'. ${ }^{56}$ This does not eliminate the role of the nation in multidirectional and dynamic mnemonic processes. However, it places the nation at the intersection of a plurality of mnemonic interests, actors and ultimately also epistemologies with distinct histories and often transnational origins. Let us by way of conclusion once more return to Ludwig Leichhardt, to illustrate some of the complexities involved.

Our own search for Leichardt in Pioneers Memorial Park was entangled in a whole range of previous mnemonic dynamics. On the one hand, the various presences and absences of Leichhardt in the municipality of Leichhardt are a result of a complex dynamic between traditions "invented" ${ }^{57}$ in the processes of Australian nation building, including ones that silenced (and continue to silence) Indigenous voices. On the other, those presences and absences are the consequence of a whole set of partly contradictory memory practices in a sliding and re-configuring Germany (from Prussia to the Kaiserreich, from Weimar to Hitler, from the two Germanies to the unified Federal Republic). And yet at the same time, they are the product of a changing set of geopolitical (im)possibilities between those various trajectories, running from rejection and ignoring, through appeasement and accommodation, to the ostentatious affirmation of connections. When combined with vagaries of individual memory and interest, this complex substrate causes the missing Leichhardt to pop up in expected as well as unpredictable ways.

The 1988 bas relief at Leichhardt Town Hall is only one of innumerable examples. When the Sydney district of Leichhardt was officially declared a municipality in 1871, the German explorer and scientist was still a man of fame in both Australia and Europe. Yet when Germany took possession of Papua in 1884 and thus became an imperial rival at 
Australia's doorstep, the image of Leichhardt began to dramatically change. Leichhardt turned from a German-Australian hero into an essentially 'unaustralian' intruder. ${ }^{58}$ In his volumes on The History of Australian Exploration (1888) and Australian Explorers (1908), Ernest Favenc, an Australian explorer, journalist, historian and novelist born in England yet curiously raised in Berlin, captured the spirit when declaring that Leichhardt had no understanding of 'mateship' nor 'bushmanship', and was thus 'of necessity, an absolute failure'. ${ }^{59}$ Although there were minor Leichhardts who emerged, for example in the translation and bibliographic work of the Jewish émigré Ludwig Louis Politzer, ${ }^{60}$ or in feminist geologist Catherine Drummond Cotton's biography, ${ }^{61}$ the two World Wars did not do the collective memory of Leichhardt in Australia much better. Alec Chisholm's aforementioned 1941 popular history Strange New World radicalised Favenc's Leichhardt into a romantic megalomaniac of Hitleresque proportions, whom Patrick White then installed firmly in the world literary canon with Voss. As Voss more than anyone else, Leichhardt then travelled back again to the two Germanies, where he collided or congealed with other Leichhardts and other trajectories of Leichhardt memory. ${ }^{62}$

It is no real surprise, then, that Pioneers Memorial Park in Leichhardt is no longer a lieu de memoire for Leichhardt himself. And yet it is significant how Leichhardt reappeared in 1988, including as a bas relief by a East German sculptor in Leichhardt Town Hall. With this new site, a different yet not entirely unrelated trail of Leichhardt memory travelled back to Australia. Although GDR commemoration like this opened up space for various private transcripts, the public dimension of the trail is in many ways just as much a mnemonic distortion as the anti-German interpretations of Leichhardt in the wake of Favenc, Chisholm and White. It was fostered and pushed by GDR cadres who bent him into an anti-imperial colonist and explorer against the alleged neo-imperialism of the rival German state. ${ }^{63}$ Put differently, they too pushed Leichhardt from straddling Myall Creek, and sought to put him on a firm footing on one bank, commemorating him as a good German, strategically separated from the British settler colonial project.

The GDR cadres were more than aware of Indigenous Australian memories of early Australian exploration, not least on the occasion of the Bicentennial celebrations, which for Aboriginal people marked 200 years of displacement and genocidal destruction. The cadres did foster Indigenous protest, including by inviting the Indigenous rock band No 
Fixed Address to perform at the 1988 Festival of Political Song in East Berlin. However, the GDR's participating in the Bicentennial celebrations undermined the gesture. And so did another feature of the East German state's honouring of Leichhardt's and other German scientists' contributions to Australia: For in 1988, the State promoted the renewed display and analysis of a set of Indigenous skulls supplied by Ferdinand von Mueller in Melbourne to Rudolf Virchow in Berlin, a collection that the GDR had inherited. ${ }^{64}$ The bas relief in Leichhardt Town Hall thus remains as a highly ambivalent lieu de memoire burdened with a whole range of intersecting memories; of memories which foster images of the German and the Australian that are as contradictory as they are inextricably entwined.

\section{The Chapters}

The chapters in this volume do not aspire to comprehensively chart the diverse fields of German-Australian colonial entanglement and the ways in which they have been and are remembered in various locations, both in Germany and Australia. Rather, they highlight select historical discourses, events, objects, anecdotes or works of art which each allow us to focus the intricacies of memory and entanglement in different ways. Taken together, we hope that they build a kaleidoscopic vision which complicates and fractures received readings of German-Australian pasts, yet still composes a clear enough picture which may direct further research.

The collection opens with an essay titled 'Recollecting Bones: The Remains of German-Australian Colonial Entanglements’ by Lars Eckstein. It critically engages with the different politics of memory involved in debates over the restitution of Indigenous Australian ancestral remains stolen by colonial actors in the nineteenth and early twentieth century and brought to Berlin in the name of science. The debates crystallise how deeply divided German scientific discourses still are over the question whether the historical and moral obligations of colonial injustice should be accepted, or whether researchers should continue to profess scientific 'disinterest'. The debates also reveal, however, an almost unanimous disavowal of Indigenous Australian knowledges and mnemonic conceptions across all camps. The bitter ironies of this disavowal transpire when Indigenous Australian 
quests for the remains of their ancestral dead lost in the limbo of German scientific collections are juxtaposed with white Australian (fictional) quests for the remains of Ludwig Leichhardt lost in the Australian interior.

Anja Schwarz continues the focus on the politics of museums and collections and the untold stories of scientific 'specimens' that travelled between Germany and Australia. In her essay, 'Schomburgk's Chook: The Entangled South Australian Collections of a German Naturalist', she reconstructs the historical, interpersonal and geopolitical contexts that made it possible for the stuffed skin of an Australian mallee fowl to become part of the collections of Berlin's Museum für Naturkunde. In doing so, she enquires into the kind of contexts that are habitually considered irrelevant when a specimen of natural history is treated as an object of taxonomic information alone. In the Museum's bird, she argues, human and non-human history become entangled in ways that link the fate of this one small Australian animal to the German revolutionary generation of 1848, to Germany's nineteenth-century colonial aspirations, to settler-Indigenous relations and the cruel realities that underpinned the production of scientific knowledge in colonial Australia, and to a present-day interest in reconstructing Indigenous knowledges.

Lindsay Barrett, too, explores such resonances of objects travelled between continents, and the entangled imaginaries tied to them - only this time the object is not a bird skin brought from Australia to Europe, but a 30-tonne German military tank, captured by Australian soldiers during the First World War in France and shipped to Brisbane to be exhibited in the Queensland Museum. In his essay, Barrett reads the tank, intriguingly named 'Mephisto' which is also the title of the essay, as the apotheosis of the nature / culture divide entrenched by nineteenth century colonialism which exported the taxonomies of the Enlightenment to the antipodes, and in return repatriated objects of flora and fauna all over Europe. Mephisto, for Barrett, thus also marks the manifestation of a German-Australian modernity: Developed from the agricultural tractor, the tank remains as a brutal and clumsy device designed purely to subdue and conquer territory.

In 'Gorgobad: Reflections on a German-Australian Family Biography’, Monica van der Haagen-Wulff continues this focus on German-Australian militarised modernities through the Second World War to the present day. In doing so, she draws on her own family history. She begins with the memories evoked by her grandparents' house in northern 
Sydney, built between 1950 and 1953. Named 'Gorgobad', Persian for 'place of the wolves', it resonates with a family history which involves German colonial investments in post-World War I Iran, the global geopolitical upheavals of the Second World War which drew her family into separate histories of refuge, British imprisonment and deportation, and, finally, building a new home in Australia. In its final twist, the essay asks pertinent questions about the entanglement of hegemonic racialised orders in Europe with the very racialised orders of the grounds on which Gorgobad was built.

The beginnings of this racialised order in Oceania, and of German involvement in it go back a long way, of course. In her chapter, 'Reports of the Cook Voyages in the Hamburgischer Correspondent', Fredericka van der Lubbe traces the line back to the years before the first formal European settlement on the Australian continent. She examines important aspects of the German journalistic reception of James Cook's voyages to the Pacific by focusing on one particular, highly networked and very widely distributed newspaper and its reporting in the period between 1767 and 1787. She uses this to show how the editors and especially London-based German-speaking correspondents consciously leveraged an Anglophilia that was typical of the Hanseatic city of Hamburg. They did so in a way that encouraged their German-speaking readers, wherever they might be, to closely identify with British exploration and even claim ownership of these events themselves. Anglophilia and the German-language reporting of the Cook voyages therefore supplied raw materials for an entangled sense of imperial identity.

In his chapter, ““A general, homogenous humanity”: The German Newspaper Der Kosmopolit, German Intellectuals and Entangled Nation-Building in Nineteenth-Century Australia', Dennis Mischke then focusses on the legacies of entangled imperial identities in the nineteenth century. He also examines a German-language newspaper, albeit one that was far less long-lived and had a much smaller circulation than the Hamburgischer Correspondent. Mischke draws new attention to members of the liberal nationalist generation of 1848, who came to the Australian colonies and became involved in intellectual activities there. He does so by applying the idea of entanglement to a durable figure that oriented one of the German-language newspapers that this group formed, Der Kosmopolit, which was printed in South Australia between 1856 and 1857. Against simplistic notions that would view cosmopolitanism as the opposite of nationalism, 
Mischke argues that individuals like Gustav Droege or Carl Muecke deployed what he calls an entangled 'Cosmo-nationalism' in ways that both advanced German nationalism, as well as powered their own engagement with and investment in Australian colonial society.

Such ambiguities and ambivalences are also at work in the histories of GermanAustralian missionary activity. In her essay “"Poor heathens”, “Cone-headed natives”, and "Good water": The Production of Knowledge of the Interior of Australia through German Missionary Texts around the 1860s', Felicity Jensz revisits the histories of two German mission stations in the South Australian Lake Eyre basin, the Lutheran Hermannsburg mission at Kallalpaninna, and the Moravian mission at Kopperamanna. By critically reviewing the textual archive around the two stations - both in the form of distinctly religious material such as mission journals, and of secular texts in German-language newspapers or scientific journals such as Petermann's Mittheilungen - she carves out the multiple entanglements of these stations far beyond their missionary activity: entanglement in German domestic affairs as well as German diasporic politics; in debates over scientific advancement as well as British colonial expansion.

Our volume closes, finally, with Andrew Wright Hurley and his chapter 'Remembering Hermannsburg and the Strehlows in Cantata Form: Music, the GermanAustralian Past and Reconciliation'. He uses the 2003 symphonic Cantata, Journey to Horseshoe Bend, to examine some of the different entangled memories of German missionisation in Central Australia, including those held by the settler-European librettist, Gordon Kalton Williams, members of the Indigenous Ntaria community choir, and others. Rather than simply reading this as a pernicious settler-Australian appropriation of Aboriginal culture, or as a story of harmonious intercultural collaboration, Hurley seeks to open up the multiplicity of meanings, the consonances, as well as the ambiguities and the disconcerting moments of uncanniness and clash that lie beneath the surface of a musical act of memory.

\section{Acknowledgements}


This publication has been generously supported by three research projects conducted between 2011 and 2016, funded by the German Academic Exchange Service (DAAD) and the Australian Technology Network of Universities (ATN) and hosted by the University of Potsdam and the University of Technology Sydney. We would like to thank a number of people who greatly contributed to these projects, especially Lindsay Barrett and Anja Schwarz, who were co-editors of the Special Issue of Postcolonial Studies from which this book sprung, but who have been less involved in the latter process. We are also indebted to others who are not included in this volume. First and foremost, Katrina Schlunke, who provided great impetus and who fostered us to think and rethink our ideas. Thanks to Katrina and Susan Brock for their hospitality in Mount Victoria, at an event that we will all warmly remember. Thanks also to Lisa Nechutnys, and to other postgraduate students associated with the project. Finally, Monica Gutierrez and Farai von Pentz were indispensable in the processes of preparing the manuscript of this book for publication.

\footnotetext{
${ }^{1}$ Ludwig Leichhardt, Journal of an Overland Expedition in Australia, from Moreton Bay to Port Essington, a Distance of upwards of 3000 Miles, during the Years 1844-1845, London: T\&W Boone, 1847.

2 Or rather, almost without a trace: A brass gun plate, located sometime around 1900 and purchased by the National Museum of Australia in 2006 has been authenticated as having belonged to that third expedition, even though much about where it was found and about its biography remains opaque. See e.g. David Hallam, Ian D. McLeod and Matthew Higgins, 'Finding Evidence of a Lost Explorer: Ludwig Leichhardt 1848 not just a Nameplate and a Provenance Study?' METAL 7.1, 2006, pp 73-77.

${ }^{3}$ Compare Ludwig Leichhardt, The Leichhardt Diaries: Early Travels in Australia During 18421844, eds Roderick J. Fensham and Thomas A. Darragh, trans Darragh, Brisbane: Queensland Museum, 2013.

${ }^{4}$ Robert Lynd, 'Lines addressed to the Party proceeding on the track of Dr. Leichhardt', Sydney Morning Herald, 3 July, 1845.

${ }^{5}$ Compare e.g. Gideon Lang, The Aborigines of Australia in their Original Condition and in their Relations with the White Men, Melbourne: Wilson \& Mackinnon, 1865; Timothy Bottoms, Conspiracy of Silence: Queensland's Frontier Killing Times, Sydney: Allen \& Unwin, 2013.

${ }^{6}$ Leichhardt, Leichhardt Diaries, p 227.
} 
${ }^{7}$ Simon Ryan, The Cartographic Eye: How Explorers Saw Australia, Melbourne: Cambridge University Press, 1996.

${ }^{8}$ Ludwig Leichhardt, Dr. Ludwig Leichhardts Briefe an seine Angehörigen, eds Georg Neumayer and Otto Leichhardt at the request of the Geographical Society in Hamburg, Hamburg: L. Friederichsen \& Co., 1881; Ludwig Leichhardt, Dr. Ludwig Leichhardt's letters from Australia during the years March 23, 1842 to April 3, 1848, ed and trans Ludwig Louis Politzer, Melbourne: Pan Press, 1944; Ludwig Leichhardt, The Letters of F.W. Leichhardt, vols. 1-3, ed and trans Marcel Aurousseau. London: Cambridge University Press, 1968.

${ }^{9}$ Patrick White, Voss, Harmondsworth: Penguin Books, 1957.

${ }^{10}$ A character in Patrick White's novel Voss (based to a significant degree on the historical figure of Leichhardt and his negative Australian reception) describes this split as the combination of German mysticism and German precision. White, Voss, p 104.

${ }^{11}$ Rebecca Wood, 'Frontier Violence and the Bush Legend: The Sydney Morning Herald's Response to the Myall Creek Massacre Trials and the Creation of Colonial Identity', History Australia 8.3, 2009, pp 1-19; Bruce Elder, Blood on the Wattle: Massacres and Maltreatment of Aboriginal Australians since 1788, Sydney: New Holland, 2003.

${ }^{12}$ Leichhardt, Leichhardt Diaries, p 28.

${ }^{13}$ We should observe that although Leichhardt is, to this day, primarily remembered either through the peculiar lens of Voss, or as a disinterested explorer and scientist, at different times he toyed with laying his intellectual endeavours to one side, and throwing his lot in with British colonial settlers, including the Scotts. His diaries and letters indicate how seriously he considered his prospects in this line. Perhaps it was an accident that he entered folklore and myth rather than the annals of the Hunter Valley's history of wine-making.

${ }^{14}$ Robert Sellick and Marlis Thiersch, 'Biographical Aspects of Leichhardt's Diaries', in Heinrich Lamping and Max Linke, eds, Australia: Studies on the History of Discovery and Exploration, Frankfurt am Main: Institut für Wirtschafts- und Sozialgeographie der Johann Wolfgang GoetheUniversität, 1994, pp 139-148.

${ }^{15}$ Leichhardt, Leichhardt Diaries, p 43.

16 Johann Friedrich Blumenbach, On the Natural Varieties of Humankind [1775], in The Anthropological Treatises of Johann Friedrich Blumenbach, ed and trans Thomas Bendyshe, Boston: Longwood Press, 1978; Andrew W. Evans, Anthropology at War: World War I and the Science of Race in Germany, Chicago: Cambridge University Press, 2010, p 27.

${ }^{17}$ Leichhardt, Leichhardt Diaries, p 313.

18 Tony Jefferies, 'Leichhardt: His Contribution to Australian Aboriginal Linguistics and Ethnography, 1843-44', Memoirs of the Queensland Museum/Culture 7.2, 2013, pp 633-652. Scholars including Felix Driver refer to this as a co-production of knowledge. See Felix Driver, 'Intermediaries and the Archives of Exploration', in Shino Konishi, Maria Nugent and Tiffany Shellam, eds, Indigenous Intermediaries: New Perspectives on Exploration Archives, Canberra: ANU Press and Aboriginal History, 2015, pp 11-29.

${ }^{19}$ Leichhardt, Overland Expedition; compare Ian D. Clark and Fred Cahir, eds, The Aboriginal Story of Burke and Wills: Forgotten Narratives, Collingwood: CSIRO Publishing, 2013.

${ }^{20}$ Dane Kennedy, The Last Blank Spaces: Exploring Africa and Australia, Cambridge, MA: Harvard University Press, 2013, p 159.

${ }^{21}$ Leichhardt, Leichhardt Diaries, p 324-325. 
${ }^{22}$ Leichhardt, Leichhardt Diaries, p 325.

${ }^{23}$ The following part of this essay (part 2) was published in an earlier form in Andrew Wright Hurley, Ludwig Leichhardt's Ghosts: The Strange Career of a Traveling Myth, Rochester, NY: Camden House, 2018. Thanks to Jim Walker from Camden House for agreeing to our use of it here.

${ }^{24}$ Launa Partlett, 'Poems', typescript, 1963, NLA MS 965; Marcel Aurousseau, 'Sesqui-centenary of the birth of Ludwig Leichhardt', The Australian Geographer 9.3, 1964, p 176.

${ }^{25}$ Gerhard Fischer, Enemy Aliens: Internment and the Homefront Experience in Australia, 19141920, St Lucia: University of Queensland Press, 1989; John F. Williams, German Anzacs and the First World War, Sydney: UNSW Press, 2003.

${ }^{26}$ Alec Chisholm, Strange New World, Sydney: Angus \& Robertson, 1941. See also Elsie Webster, Whirlwinds in the Plain: Ludwig Leichhardt, Friends, Foes and History, Melbourne: Melbourne University Press, 1980; as well as Angus Nicholls, 'Leichhardt and "Voss" revisited', in Ian Henderson and Anouk Lang, eds, Patrick White beyond the Grave: New Critical Perspectives, London and New York: Anthem Press, 2015, pp 35-63.

${ }^{27}$ Darrell Lewis, Where is Dr Leichhardt? Clayton: Monash University Publishing, 2013.

${ }^{28}$ Susan K. Martin, 'Dead White Male Heroes: Ludwig Leichhardt and Ned Kelly in Australian Fiction', in Judith Ryan and Chris Wallace-Crabbe, eds, Imagining Australia: Literature and Culture in the New New World. Cambridge, MA and London: Harvard University Press, 2004, pp 23-52, here p 27; see also Christy Collis, 'Walking in Your Footsteps: Footsteps of the Explorers Expeditions and the Contest for Australian Desert Space', in Simon Naylor and James R. Ryan, eds, New Spaces of Exploration: Geographies of Discovery in the Twentieth Century, London and New York: I.B. Tauris, 2010, pp 222-240.

${ }^{29}$ Hall Greenland, Red Hot: The Life \& Times of Nick Origlass: The Story of Balmain's Revolutionary, Sydney: Wellington Lane Press, 1998; Michael Hogan, Local Labor: A History of the Labor Party in Glebe, Annandale: Federation Press, 2004.

${ }^{30}$ Lindsay Barrett, 'Die vielen Leben des Ludwig Leichhardt', in Heike Hartmann, ed, Der Australienforscher Ludwig Leichhardt: Spuren eines Verschollenen, Berlin: be.bra wissenschaft verlag, 2013 pp 19-37.

${ }^{31}$ Andrew W. Hurley and Anja Schwarz. "“The greatest son of our Heimat”: Reading German Leichhardts across the National Socialist Era', Journal of Australian Studies 39.4, 2015, pp 529545.

32 Peter Monteath, 'The German Democratic Republic and Australia', Debatte: Journal of Contemporary Central and Eastern Europe, 16.2, 2008, pp 213-235; Andrew W. Hurley. 'Son of the Soil, Proto-Socialist or Free Spirit? Heinz Haufe's Entdeckungsreisen in Australien and the Rehabilitation of Ludwig Leichhardt in East Germany', Limbus: Australian Yearbook of German Literary and Cultural Studies, 2013, pp 209-224; Andrew W. Hurley, 'Leichhardt's Bust, or how the Explorer was Re-discovered during the Cold War', Continuum 28.6, 2014, pp 885-900.

${ }^{33}$ Qtd. in Konstantin Laurenz, 'Wie Leichhardts Büste nach Canberra kam', Cottbusser Rundschau 3 July, 2004.

${ }^{34}$ Andrew W. Hurley, 'No Fixed Address, but Currently in East Berlin: The Australian Bicentennial, Indigenous Protest and the Festival of Political Song in 1988', Perfect Beat 15.2, 2014, pp 129-148; Hurley, 'Leichhardt’s Bust'.

35 Untitled undated typescript, Bundesarchiv Stiftung Archiv der Parteien und Massenorganisationen der DDR, file N 2558/13. On Salomon's connections with the leftists at 
Leichhardt Town Hall and her visit in 1984 to Australia, see Gertrud Salomon, 'Der Humboldt Australiens', Die Wochenpost 39, 1984, pp 12-13.

${ }^{36}$ Heike Hartmann, ed, Der Australienforscher Ludwig Leichhardt: Spuren eines Verschollenen, Berlin: be.bra wissenschaft verlag, 2013.

${ }^{37}$ Lindsay Barrett, Lars Eckstein, Andrew Wright Hurley and Anja Schwarz, eds 1001 Leichhardts, Brisbane: Queensland Museum, https://leichhardt.qm.qld.gov.au/1001+Leichhardts.

${ }^{38}$ See Patrick Wolfe, Settler Colonialism and the Transformation of Anthropology: The Politics and Poetics of an Ethnographic Event, London: Cassel, 1999; and Patrick Wolfe, 'Settler Colonialism and the Elimination of the Native', Journal of Genocide Research 8.4, 2006, pp 387409. For a more general overview, see Fiona Bateman and Lionel Pilkington, eds, Studies in Settler Colonialism: Politics, Identity and Culture, New York: Palgrave Macmillan, 2011.

${ }^{39}$ Augustin Lodewyckx, Die Deutschen in Australien, Stuttgart: Ausland-und-Heimat-VerlagsAktiengesellschaft, 1932; see also Albert Heising, Die Deutschen in Australien, Berlin: Wohlgemuth, 1853. For a general history of the German-language historiography on Australia, see Henriette von Holleuffer, 'The Missing Fifth Dimension: The Writing of Australian History in Germany', Australian Journal of Politics and History 54.3, 2008, pp 450-63. Other contributions to German-Australian studies include outliers like Werner P. Friedrich, Australia in Western Imaginative Prose Writings, 1600-1960: An Anthology and a History of Literature, Chapel Hill: University of North Carolina Press, 1967; as well as a great number of works emanating from Australian scholars. This includes Leslie Bodi's many early contributions (for a partial bibliography of his works, see Walter Veit and Michael Clyne, eds, Antipodische Aufklärungen/Antipodean Enlightenments: Festschrift für Leslie Bodi, New York: Peter Lang, 1987); works associated with a range of anniversaries in the 1980s, often written in the spirit of multiculturalism, and a new acknowledgement of non-British 'ethnic' contributions (see e.g. Alan Corkhill and Manfred Jurgensen, eds, The German Presence in Queensland over the Last 150 Years: Proceedings of an International Symposium August 24, 25 and 26, 1987, University of Queensland, Brisbane, Australia, St. Lucia: University of Queensland Department of German, 1988; Alan Corkhill, Antipodean Encounters: Australia and the German Literary Imagination, 1754-1918, Bern and New York: Peter Lang, 1990; Irmtraud Petersson, German Images in Australian Literature, Frankfurt am Main: Peter Lang, 1990; Manfred Jurgensen, Eagle and Emu: German-Australian Writing, 1930-1990, St Lucia: University of Queensland Press, 1992; and, as an update to these, Jürgen Tampke, The Germans in Australia: The Story of the Continent's German Speaking Communities, Melbourne: Cambridge University Press, 2006). There have been numerous contributions on specific aspects, works, events or figures, which we cannot even sketch here. There is also an extensive literature about aspects of later, twentieth-century engagements. In terms of recent edited volumes, also covering the colonial era proper, see e.g. Andrea Bandhauer and Maria Veber, eds, Migration and Cultural Contact: Germany and Australia, Sydney: Sydney University Press, 2009; and Peter Monteath, Germans: Travellers, Settlers and Their Descendants in South Australia, Kent Town, SA: Wakefield Press, 2011. For a recent critical overview of the literature, see Gerhard Fischer, 'Debating the "German Presence” in Australia: Notes on Research and Research Desiderata', in Bandhauer and Veber, Migration, pp 131-152. In Germany, a number of scholars of English-language literatures, and Australianists have contributed to the literature (see e.g. Volker Wolf, Die Rezeption australischer Literatur im deutschen Sprachraum von 1845-1979, Tübingen: Stauffenberg, 1982; Volker Wolf, ed, Australien: Deutsche - zumeist literarische Impressionen aus 150 Jahren, Bern and New York: Peter Lang, 1992; Gerhard Stilz and Heinrich Lamping, eds, Australienstudien in Deutschland: Grundlagen und Perspektiven, Bern and New York: Peter Lang, 1990; Heinrich Lamping and Max Linke, eds, Australia: Studies on the History of Discovery and Exploration, Frankfurt am Main: Institut für Wirtschafts- und Sozialgeographie der Johann Wolfgang Goethe-Universität, 1994; and others). 
${ }^{40}$ See e.g. the bibliographies L.L. Politzer, Bibliography of German literature on Australia, 17701947, Melbourne: Pan Press, 1952; Leslie Bodi, Stephen Jeffries and Susan Radvansky, eds, Image of a Continent: a Bibliography of German Australiana from the Beginnings to 1975/ Bild eines Kontinents: eine Bibliographie deutscher Australiana von den Anfängen bis 1975, Wiesbaden: O. Harrasowitz, 1990. See Corkhill, Antipodean Encounters for a survey. For the period between 1930 and 1990, see Jurgensen, Eagle and Emu.

${ }^{41}$ Rod Home, Science as German Export to Nineteenth Century Australia, Working Papers in Australian Studies 104, London: University of London, 1994. On German naturalists' and others' engagements with the British Empire, see generally Ulrike Kirchberger, Aspekte deutsch-britischer Expansion: die Überseeinteressen der deutschen Migranten in Grossbritannien in der Mitte des 19. Jahrhunderts, Stuttgart: F. Steiner, 1999; John R. Davis, The Victorians and Germany, Oxford: Peter Lang, 2007; John R. Davis, Stefan Manz and Margrit Schulte Beerbühl, eds, Transnational Networks: German Migrants in the British Empire, 1670-1914, Boston: Brill, 2012. On the Forsters, see e.g. Fredericka van der Lubbe's contribution to this volume and the literature she cites in it. On Mueller, see, particularly Edward Kynaston, A Man on Edge: A Life of Baron Sir Ferdinand von Mueller, Ringwood: Allen Lane, 1981; Edward Kynaston, 'Exploration as Escape: Sir Ferdinand von Mueller', in David Walker and Jürgen Tampke, eds From Berlin to the Burdekin: The German Contribution to the Development of Australian Science, Exploration and the Arts, Kensington: UNSW Press, 1991, pp 3-21; Johannes H. Voigt, ed Die Erforschung Australiens: der Briefwechsel zwischen August Petermann und Ferdinand von Mueller, 1861-1878, Gotha: Perthes, 1996; Rod Home et al., eds, Regardfully Yours: Selected Correspondence of Ferdinand von Mueller, vols. 1-3, Bern: Peter Lang, 1998-2006; and Ulrike Kirchberger, 'Ludwig Leichhardt und die transnationalen Gelehrtennetzwerke des britischen Empire’, in Hartmann, Leichhardt, pp 7994.

${ }^{42}$ On German emigration to Australia, see generally Tampke, Germans in Australia. On the 1848ers in Australia, see e.g. Fischer “"A Great Independent Reich and Nation”: Carl Muecke and the "Forty-Eighters" of the German-Australian Communitiy of South Australia', Journal of Australian Studies 25, Nov. 1989, pp 85-100, as well as publications by Leslie Bodi (referred to in Veit and Clyne, Antipodische Aufklärungen), and by Dennis Mischke in this volume. For a comparative perspective, see also Stephen Manz, Constructing a German Diaspora: The "Greater German Empire”, 1871-1914, New York: Routledge, 2014.

43 There is an extensive literature on the Strehlows, father and son, to which we can only gesture here. See e.g. Walter Veit, 'In Search of Carl Strehlow: Lutheran Missionary and Australian Anthropologist', in Walker and Tampke, From Berlin, pp 108-34; Anna Kenny, The Aranda's Pepa: An Introduction to Carl Strehlow's Masterpiece, Die Aranda und Loritja-Stämme in Zentral Australien (1907-1920), Canberra: ANU E-press, 2013; and the literature cited in Andrew Hurley's chapter.

${ }^{44}$ Roslyn Poignant, Professional Savages: Captive Lives and Western Spectacle, Sydney: Sydney University Press, 2004.

${ }^{45}$ Heidi Zogbaum, Changing Skin Colour in Australia: Herbert Basedow and the Black Caucasian, North Melbourne: Australian Scholarly Publishing, 2010.

${ }^{46}$ On Kirchner, see e.g. Corkhill, Antipodean Encounters, as well as Patricia Cloos and Jürgen Tampke, eds, Greetings From the Land Where Milk and Honey Flows: The German Emigration to NSW 1838-1858, Canberra: Southern Highlands Publishing, 1993; on Godeffroy, see e.g. passages in Ray Sumner's biography of Amalie Dietrich, Godeffroy's collector in Queensland in the 1860s and 1870s (Ray Sumner, A Woman in the Wilderness: The Story of Amalie Dietrich in Australia, Kensington: UNSW Press, 1993); on German merchants in the British colonies more generally, see 
e.g. Bradley Naranch, Beyond the Fatherland: Colonial Visions, Overseas Expansion and German Nationalism, 1848-1885, PhD Thesis. Johns Hopkins University, 2006.

${ }^{47}$ Susanne Zantop, Colonial Fantasies: Conquest, Family, and Nation in Precolonial Germany, 1770-1870, Durham: Duke University Press, 1997; Sara Friedrichsmeyer, Sara Lennox and Susanne Zantop, eds, The Imperialist Imagination: German Colonialism and Its Legacy, Ann Arbor: University of Michigan Press, 1998; Russell A Berman, Enlightenment or Empire: Colonial Discourse in German Culture, Lincoln, Nebraska: University of Nebraska Press, 1998.

${ }^{48}$ Paul M. Kennedy, The Rise of the Anglo-German Antagonism, 1860-1914, London: Allen \& Unwin, 1980.

${ }^{49}$ Kirchberger, Aspekte.

${ }^{50}$ Ulrike Kirchberger and Heather Ellis, eds, Anglo-German Scholarly Networks in the Long Nineteenth Century, Leiden: Brill, 2014.

${ }^{51}$ Some work on the World War I era of internment and erasure of German names and hyphenated identity, as well as what Horst Priessnitz once called the 'Vossification' of Leichhardt are exceptions (see e.g. Fischer, Enemy Aliens; Horst Priessnitz, 'The "Vossification" of Ludwig Leichhardt', in Walker and Tampke, From Berlin, pp 196-217; Williams, German Anzacs; and to a certain extent Webster, Whirlwinds).

${ }^{52}$ Maurice Halbwachs, On Collective Memory, ed, trans and intr Lewis A. Coser, Chicago, IL: The University of Chicago Press, 1992; Pierre Nora, The Realms of Memory: Rethinking the French Past, ed Lawrence D. Kritzman, trans Arthur Goldhammer, New York: Columbia UP, 1996; Aleida Assmann, Erinnerungsräume: Formen und Wandlungen des kulturellen Gedächtnisses, Munich: C.H. Beck, 1999.

${ }^{53}$ For a critique of the Eurocentric limits of Aleida Assmann's conceptions of memory, see Eckstein in this volume.

${ }^{54}$ Michael Rothberg, Multidirectional Memory: Remembering the Holocaust in the Age of Decolonization, Stanford, CA: Stanford UP, 2009.

${ }_{55}$ Astrid Erll, 'Travelling Memory', Parallax, Special Issue Transcultural Memory, ed Rick Crownshaw 17.4, 2011, pp 4-18.

${ }^{56}$ Erll, ‘Travelling Memory', p 8.

${ }^{57}$ Eric Hobsbawm und Terence Ranger, The Invention of Tradition, Cambridge University Press, Cambridge 1992.

${ }^{58}$ See generally, Webster, Whirlwinds.

${ }^{59}$ Ernest Favenc, The Explorers of Australia and their Life Work, Christchurch et al.: Whitcomebe and Tombs, 1908, p 100; Ernest Favenc, The History of Australian Exploration from 1788 to 1888: Compiled from State Documents, Private Papers and the Most Authentic Sources of Information, Sydney: Turner and Henderson, 1888.

${ }^{60}$ Leichhardt, Leichhardt's Letters; Politzer, Bibliography.

${ }^{61}$ Catherine Drummond Cotton, Ludwig Leichhardt and the Great South Land, Sydney: Angus \& Robertson, 1938.

${ }^{62}$ Volker Wolf, 'A Note on the Reception of Patrick White’s Novels in German Speaking Countries (1957-1979)', Australian Literary Studies 11.1, 1983, pp 108-119; Thomas M. Stein, Patrick White: Voss, Munich: Wilhelm Fink, 1983; Bernhard Scheller, 'Nachbemerkung' to Patrick White, Voß, Leipzig: Reclam, 1987: 463-468. 
${ }^{63}$ On the public and private transcripts that featured in the commemorative landscape in the GDR, see Jan Palmowski, Inventing a Socialist Nation: Heimat and the Politics of Everyday Life in the GDR, 1945-1990, Cambridge: Cambridge University Press, 2009.

${ }^{64}$ Anon, Abstracts for the conference, 'Beiträge und Studien zur Erforschung und Erschließung Australiens unter besonderer Würdigung Ludwig Leichhardts und weiterer deutscher Wissenschaftler', held in Chossewitz bei Beeskow (GDR), October 1988. Copy in the collection of the Ludwig Leichhardt Museum, Trebatsch. 